\title{
Serological classification in relation to auxotypes, plasmid contents, and susceptibilities to antimicrobials of PPNG and non-PPNG strains isolated in Greece
}

\author{
G TZANAKAKI, L MAVROMMATI, E TZELEPI, S KOLYVA, E FRAGOULI
}

From the Bacteriology Department, Hellenic Pasteur Institute, Athens, Greece

SUMMARY Thirty three penicillinase producing Neisseria gonorrhoeae (PPNG) and 152 non-PPNG strains were serologically classified in relation to their patterns of resistance to antimicrobials, nutritional requirements (auxotypes), and plasmid contents. Of the 185 strains, $65(35 \%)$ belonged to the WI and $120(65 \%)$ to the WII/III serogroup, the predominant serovars of which were Arost and Bropt, respectively. Associations between serotype and susceptibility to antimicrobial agents, auxotype, and plasmid content were observed. Of the 152 non-PPNG strains, $112(74 \%)$ belonged to serogroup WI. The WI non-PPNG strains were more sensitive to penicillin, thiamphenicol, tetracycline, and cefotaxime than the WII/III non-PPNG strains. Auxotyping and serogrouping the strains showed no differentiation other than that arginine, hypoxanthine, and uracil dependent $\left(\mathrm{AHU}^{-}\right)$strains belonged to serogroup WI. The proline, citrulline, and uracil dependent (PCU $\left.{ }^{-}\right)$ strains belonged, as expected, to serogroup WII/III. Analysing the 33 PPNG strains showed that of 21 carrying the 4.5 megadalton (Asian type) penicillin resistance plasmid, $17(81 \%)$ belonged to serogroup WI, with serovar Arst predominating, and only four (19\%) to serogroup WII/III. Of 11 isolates carrying the 3.2 megadalton (African type) resistance plasmid, seven (64\%) belonged to serogroup WI (serovar Av predominating) and four (36\%) to WII/III (with serovar Bropyst predominating). One strain carried the 3.05 megadalton penicillin resistance plasmid (Toronto type), belonged to the WI serogroup, and had serovar Arost.

To obtain a better understanding of the epidemiology of gonococcal infections, reliable methods based on the different characteristics of strains of Neisseria gonorrhoeae are necessary. The discovery by Catlin that $N$ gonorrhoeae strains could be divided into groups based on their nutritional requirements provided the first practical method for typing gonococci, which has become invaluable in epidemiological investigation. ${ }^{\prime}$ Knowledge of the composition of the gonococcal outer membrane also led to the production of monoclonal antibodies specific for $N$ gonorrhoeae and to its classification into WI and WII/III serogroups. ${ }^{2-5}$ Thus in any given geographical area or clinical situation a few dominant serovars, or reaction patterns, have been shown by these monoclonal antibodies, ${ }^{5}$ which are therefore

Address for reprints: Dr G Tzanakaki, Bacteriology Department, Hellenic Pasteur Institute, 127 Vas Sofias Avenue, 11521 Athens, Greece

Accepted for publication 18 January 1989 valuable epidemiological tools. Assessing the resistance of $N$ gonorrhoeae to antimicrobials and studying its genetic basis is also important not only for successful treatment but also as an epidemiological marker.

These typing techniques have been invaluable in tracking microepidemics within countries as well as in monitoring the international dissemination of gonococcal strains, particularly penicillinase producing $N$ gonorrhoeae (PPNG) strains ${ }^{46-8}$ and also those chromosomally resistant to antibiotics.

The present study was undertaken to characterise the Greek PPNG and non-PPNG strains by auxotype, plasmid content, and serovar; to develop a data base for future comparisons; and to ascertain, if possible, the origin of certain strains.

\section{Patients, materials, and methods}

BACTERIAL STRAINS

Thirty three PPNG and 152 non-PPNG strains were isolated from men with acute urethritis who attended the Andreas Syngros venereal hospital as outpatients. 
As control strains for auxotyping and for analysing plasmid DNA, we used 1347 arginine requiring strains (auxotype $\mathrm{Arg}^{-}$) with the 3.2 Mdalton penicillin resistance plasmid and the 2.6 Mdalton cryptic plasmid and 1745 prototrophic (auxotype Zero) strains with the 24.5 Mdalton conjugative plasmid in association with the 4.5 Mdalton penicillin resistance plasmid and the cryptic plasmid. To measure minimum inhibitory concentrations (MICs) of antibiotics we used the five reference strains proposed by the World Health Organisation. ${ }^{10}$

We stored all strains at $-70^{\circ} \mathrm{C}$ in heart infusion broth (Oxoid) supplemented with $20 \%$ (v/v) glycerol.

\section{GROWTH AND IDENTIFICATION}

We used selective and non-selective media and the substrates designated by Diagnostics Pasteur under appropriate conditions of temperature, humidity, and carbon dioxide.

\section{MEASURING MIC}

We used the agar dilution method with the nonselective medium provided by Diagnostics Pasteur." The antibiotics used were penicillin (Sigma), spectinomycin (Upjohn), thiamphenicol (Clin-Midy), tetracycline (Hoechst), and cefotaxime (Roussel).

\section{DETECTING BETA-LACTAMASE}

We tested for $\beta$-lactamase activity using the chromogenic cephalosporin substrate, Nitrocefin (Oxoid).

\section{AUXOTYPING}

For auxotyping we used the chemically defined media and the technical procedures described by Catlin ${ }^{12}$ and Hendry and Stewart. ${ }^{13}$

ELECTROPHORETIC ANALYSIS OF PLASMID DNA We undertook agarose gel $(0.7 \%$, Beecham) electrophoresis of plasmid DNA according to Portnoy ${ }^{14}$ and partial DNA purification as described by Maniatis. ${ }^{15}$

\section{SEROTYPING BY COAGGLUTINATION}

We performed serological characterisation of the gonococcal strains by coagglutination using the $\mathrm{Ph}$ panel of monoclonal antibodies to protein I and the methods described by Bygdeman et al. ${ }^{2}$ We thought that the $\mathrm{Ph}$ panel would be sufficient for our serological classification because the specificity of the two existing panels, $\mathrm{GS}$ and $\mathrm{Ph}$, and the designation of specific serovars have already been compared. ${ }^{16}{ }^{17}$ The serotyping procedure was as follows: whole cells of $N$ gonorrhoeae were suspended in phosphate buffered saline (PBS) and heated at $100^{\circ} \mathrm{C}$ for 30 minutes. One drop of coated staphylococci was mixed with an equal volume of boiled gonococci on a microtitre bioplate
(Lindigö, Sweden), which was rocked gently for two minutes. The degree of agglutination was then noted. Control tests performed with uncoated protein A staphylococci were always included.

\section{Results}

Of our 185 gonococcal isolates examined, $65(35 \cdot 1 \%)$ were in the WI and $120(64.9 \%)$ in the WII/III serogroup. Thirty three were PPNG strains, of which $25(75.8 \%)$ belonged to the WI and eight $(24.2 \%)$ to the WII/III serogroup. Of the 152 non-PPNG isolates, $40(26.3 \%)$ were in the WI and $112(73.7 \%)$ in the WII/ III serogroups. The serovars are shown in table 1.

AUXOTYPES, SEROGROUPS, AND SEROVARS

The 185 PPNG and non-PPNG strains isolated were of 11 different auxotypes. Table 2 shows the relation between auxotypes and serogroups.

In the 152 non-PPNG strains, the Zero auxotype predominated (in 92) followed by the proline requiring $\left(\mathrm{Pro}^{-}\right)$auxotype in 18 strains. The serovars predominating in strains of the Zero auxotype were Arost in the WI and Bropt in the WII/III serogroups, whereas the Pro ${ }^{-}$non-PPNG strains belonged almost exclusively $(17 / 18)$ in the WII/III serogroup with serovar Bropt predominating; the only strain in the WI serogroup was of serovar Arst (data not shown in table 2). Of the 12 strains requiring arginine, hypoxanthine, and uracil (AHU), eight $(66.7 \%)$ belonged to serogroup WI (six of which were of serovar Arost) and four belonged to serogroup WII/III and Brpyut was the predominant serovar. In contrast, most (7/9) of the strains requiring proline, citrullin, and uracil ( (CU $\left.^{-}\right)$ were in serogroup WII/III and Brpyust was the predominant serovar; the remaining two were in serogroup WI and were of serovars Arost and Arst.

Table 1 Serogroups and serovars of 185 penicillinase producing Neisseria gonorrhoeae (PPNG) and non-PPNG strains (figures are numbers (percentages) of strains)

\begin{tabular}{|c|c|c|c|c|c|c|}
\hline \multirow{2}{*}{$\begin{array}{l}\text { Serovars } \\
\text { Serogroup WI: } \\
\text { Arost } \\
\text { Arot } \\
\text { Arst } \\
\text { Av }\end{array}$} & \multicolumn{2}{|c|}{$\begin{array}{l}\text { Non-PPNG } \\
(n=152)\end{array}$} & \multicolumn{2}{|c|}{$\begin{array}{l}P P N G \\
(n=33)\end{array}$} & \multicolumn{2}{|c|}{$\begin{array}{l}\text { Total } \\
(n=185)\end{array}$} \\
\hline & $\begin{array}{r}40 \\
24 \\
0 \\
7 \\
9\end{array}$ & $\begin{array}{l}(26 \cdot 3) \\
(60 \cdot 0) \\
(17 \cdot 5) \\
(22.5)\end{array}$ & $\begin{array}{r}25 \\
1 \\
1 \\
17 \\
6\end{array}$ & $\begin{array}{r}(75.8) \\
(4 \cdot 0) \\
(4 \cdot 0) \\
(68.0) \\
(24.0)\end{array}$ & $\begin{array}{r}65 \\
25 \\
1 \\
24 \\
15\end{array}$ & $\begin{array}{r}(35.1) \\
(38.5) \\
(1.5) \\
(36.9) \\
(23.1)\end{array}$ \\
\hline $\begin{array}{l}\text { Serogroup WII/III: } \\
\text { Bpyvut } \\
\text { Bropt } \\
\text { Bropyst } \\
\text { Brpyust } \\
\text { Av/Bx } \\
\text { Other }\end{array}$ & $\begin{array}{r}112 \\
20 \\
31 \\
0 \\
12 \\
11 \\
38\end{array}$ & $\begin{array}{l}(73 \cdot 7) \\
(17 \cdot 9) \\
(27 \cdot 7)\end{array}$ & $\begin{array}{l}8 \\
1 \\
2 \\
2 \\
0 \\
0 \\
3\end{array}$ & $\begin{array}{l}(24 \cdot 2) \\
(12.5) \\
(25 \cdot 0) \\
(25 \cdot 0)\end{array}$ & $\begin{array}{r}120 \\
21 \\
33 \\
2 \\
12 \\
11 \\
41\end{array}$ & $\begin{array}{r}(64 \cdot 9) \\
(17 \cdot 5) \\
(27 \cdot 5) \\
(1 \cdot 7) \\
(10 \cdot 0) \\
(9 \cdot 2) \\
(34 \cdot 2)\end{array}$ \\
\hline
\end{tabular}

* Percentages of serovars estimated from No of strains in corresponding serogroup, percentages of serogroups estimated from total No of PPNG or non-PPNG strains. 
Table 2 Auxotypes of 33 penicillinase producing Neisseria gonorrhoeae (PPNG) and 152 non-PPNG strains in relation to WI and WII/III serogroups

\begin{tabular}{|c|c|c|c|c|c|c|c|c|c|c|}
\hline \multirow{3}{*}{$\begin{array}{l}\text { Auxotypes } \\
\text { Zero } \\
\text { Pro- }^{-} \\
\text {Arg }^{-} \\
\text {AHU- } \\
\text { PCU } \\
\text { Others* }\end{array}$} & \multicolumn{5}{|c|}{ Non-PPNG strains } & \multicolumn{5}{|c|}{ PPNG strains } \\
\hline & \multirow{2}{*}{\begin{tabular}{r|} 
No \\
92 \\
18 \\
12 \\
12 \\
9 \\
9
\end{tabular}} & \multicolumn{2}{|l|}{$W I$} & \multicolumn{2}{|c|}{$W I I / I I I$} & \multirow{2}{*}{$\begin{array}{r}\text { No } \\
15 \\
16 \\
1 \\
0 \\
0 \\
1\end{array}$} & \multicolumn{2}{|l|}{$W I$} & \multicolumn{2}{|c|}{ WII/III } \\
\hline & & $\begin{array}{r}19 \\
1 \\
5 \\
8 \\
2 \\
5\end{array}$ & $\begin{array}{r}(20 \cdot 7) \\
(5 \cdot 6) \\
(41 \cdot 7) \\
(66 \cdot 7) \\
(22 \cdot 2) \\
(55 \cdot 6)\end{array}$ & $\begin{array}{r}73 \\
17 \\
7 \\
4 \\
7 \\
4\end{array}$ & $\begin{array}{l}(79 \cdot 3) \\
(94 \cdot 4) \\
(58 \cdot 3) \\
(33 \cdot 3) \\
(77 \cdot 8) \\
(44 \cdot 4)\end{array}$ & & $\begin{array}{r}11 \\
13 \\
1 \\
0 \\
0 \\
0\end{array}$ & $\begin{array}{c}(73 \cdot 3) \\
(81 \cdot 2) \\
(4)\end{array}$ & $\begin{array}{l}4 \\
3 \\
0 \\
0 \\
0 \\
1\end{array}$ & $\begin{array}{r}(26 \cdot 7) \\
(18.8) \\
(12.5)\end{array}$ \\
\hline Total & 152 & 40 & & 112 & & 33 & 25 & & 8 & \\
\hline
\end{tabular}

Zero, prototrophic; $\mathrm{Pro}^{-}$, proline requiring; $\mathrm{Arg}^{-}$, arginine requiring; $\mathrm{AHU}^{-}$, arginine, hypoxanthine, and uracil requiring; $\mathrm{PCU}^{-}$, proline, citrulline, and uracil requiring auxotypes.

*Other auxotypes: Pro- ${ }^{-} \mathrm{Arg}^{-}$(proline and arginine requiring); Ura-, (uracil requiring); $\mathrm{His}^{-} \mathrm{Leu}^{-}$, (histidine and leucine requiring); $\mathrm{Pro}^{-} \mathrm{Arg}^{-} \mathrm{Hyx}^{-}$, (proline, arginine, and hypoxanthine requiring); His ${ }^{-}$, (histidine requiring); $\mathrm{Arg}^{-} \mathrm{Leu}^{-} \mathrm{Hyx}^{-} \mathrm{Ura}^{-}$, (arginine, leucine, hypoxanthine, and uracil requiring).

On the other hand, the 33 PPNG strains were almost equally of Pro and Zero auxotypes, except two that were of auxotype $\mathrm{Arg}^{-}$and $\mathrm{Pro}^{-} \mathrm{Arg}^{-}$(proline and arginine requiring). Most $(24 / 31,77 \cdot 4 \%)$ of the Proand Zero, as well as the one $\mathrm{Arg}^{-}$, PPNG strains belonged to serogroup WI and Arst was the predominant serovar. The one Pro Arg $^{-}$PPNG strain belonged to serogroup WII/III and was of serovar Bropyst.

\section{SEROGROUPS AND SUSCEPTIBILITY TO}

ANTIMICROBIAL OF NON-PPNG STRAINS

Table 3 shows the susceptibility to five antimicrobial agents of the 152 non-PPNG strains tested, in relation to their serogroups. The strains most susceptible to penicillin, cefotaxime, tetracycline, and thiamphenicol belonged to serogroup WI, whereas the strains belonging to serogroup WII/III were less susceptible. The strains in WI and WII/III serogroups were equally susceptible to spectinomycin.

\section{SEROGROUPS, SEROVARS, AND PLASMID CONTENTS}

Table 4 presents the relation between plasmid contents, serogroups, and serovars.

Electrophoretic analysis of the 152 non-PPNG strains showed that 95 harboured only the 2.6 megadalton cryptic plasmid, 20 harboured the 24.5 megadalton conjugative plasmid in conjunction with the 2.6 megadalton cryptic plasmid, two carried the 24.5 megadalton conjugative plasmid only, and 35 were plasmid free. The plasmid content findings, in relation to the coagglutination tests carried out for serogrouping, showed that most $(67 / 95,70.5 \%)$ of the non-PPNG strains carrying only the 2.6 megadalton cryptic plasmid belonged to serogroup WII/III, whereas $28 / 95(29.5 \%)$ were in serogroup WI. As for the 20 isolates carrying both the 24.5 megadalton and the 2.6 megadalton plasmids, $16(80 \%)$ were in the WII/III and four (20\%) in the WI serogroups. The two strains carrying only the 24.5 megadalton conjugative plasmid were in serogroup WII/III. A similar distribution was seen in the 35 plasmid free strains, with 27 $(77 \cdot 1 \%)$ belonging to the WII/III and eight $(22.9 \%)$ to the WI serogroup.

In terms of serovars, most (24) of the $\mathbf{4 0}$ WI nonPPNG strains in all four plasmid content groups were of serovar Arost, whereas various serovars dominated the 112 non-PPNG strains in the WII/III serogroup (Bropt (31), Bpyvut (20), and Brpyust (12)) depending on their plasmid content.

Electrophoretic analysis of the 33 PPNG strains divided them into two main groups, based on the type of penicillin resistance plasmid that they harboured: 21 carrying the 4.5 megadalton (Asian type), 11

Table 3 Correlation between serogroups and susceptibility to antimicrobials (minimum inhibitory concentrations (MIC) for $50 \%$ and $90 \%$ of strains) in 152 non-PPNG strains

\begin{tabular}{|c|c|c|c|c|c|c|}
\hline \multirow[b]{2}{*}{ Antimicrobial } & \multicolumn{3}{|l|}{$W I$ serogroup } & \multicolumn{3}{|l|}{ WII/III serogroup } \\
\hline & $\begin{array}{l}\text { MIC range } \\
(m g / l)\end{array}$ & $\begin{array}{l}M I C_{s 0} \\
(m g / l)\end{array}$ & $\begin{array}{l}M I C_{90} \\
(m g / l)\end{array}$ & $\begin{array}{l}\text { MIC range } \\
(\mathrm{mg} / \mathrm{l})\end{array}$ & $\begin{array}{l}M I C_{s 0} \\
(m g / l)\end{array}$ & $\begin{array}{l}M I C_{\phi 0} \\
(m g / l)\end{array}$ \\
\hline $\begin{array}{l}\text { Penicillin } \\
\text { Cefotaxime } \\
\text { Spectinomycin } \\
\text { Tetracycline } \\
\text { Thiamphenicol }\end{array}$ & $\begin{array}{l}\leqslant 0.015-8 \\
\leqslant 0.0005-0.128 \\
\leqslant 4 \quad-64 \\
\leqslant 0.125-2 \\
\leqslant 0.125-2\end{array}$ & $\begin{array}{l}0.064 \\
0.008 \\
16 \\
0.25 \\
0.5\end{array}$ & $\begin{array}{l}1 \\
0 \cdot 128 \\
32 \\
1 \\
1\end{array}$ & $\begin{array}{l}\leqslant 0.015-8 \\
\leqslant 0.0005-0.128 \\
\leqslant 4 \quad-64 \\
\leqslant 0.125-16 \\
\leqslant 0.125-8\end{array}$ & $\begin{array}{l}0.26 \\
0.032 \\
16 \\
0.5 \\
0.5\end{array}$ & $\begin{array}{l}1 \\
0 \cdot 128 \\
32 \\
2 \\
2\end{array}$ \\
\hline
\end{tabular}


Table 4 Correlation between plasmid contents, serogroups, and serovars of 185 PPNG and non-PPNG strains (figures are numbers (percentages) of strains)

\begin{tabular}{|c|c|c|c|c|c|c|c|c|c|c|c|}
\hline \multirow{3}{*}{$\begin{array}{l}\text { Serovars } \\
\text { Serogroup WI: } \\
\text { Arost } \\
\text { Arot } \\
\text { Arst } \\
\text { Av }\end{array}$} & \multicolumn{6}{|c|}{ Non-PPNG strains with plasmids: } & \multicolumn{5}{|c|}{ PPNG strains with resistance plasmids: } \\
\hline & \multicolumn{2}{|c|}{$\begin{array}{l}\text { Cryptic } \\
(2 \cdot 6 M \text { dalton }) \\
(n=95)\end{array}$} & $\begin{array}{l}\text { Conjugative } \\
(24 \cdot 5 \text { Mdalton }) \\
(n=2)\end{array}$ & \multicolumn{2}{|c|}{$\begin{array}{l}\text { Both } \\
(n=20)\end{array}$} & $\begin{array}{l}\text { Neither } \\
(n=35)\end{array}$ & \multicolumn{2}{|c|}{$\begin{array}{l}\text { African } \\
(3 \cdot 2 M \text { dalton }) \\
(n=I I)\end{array}$} & \multicolumn{2}{|c|}{$\begin{array}{l}\text { Asian } \\
(4 \cdot 5 \text { Mdalton }) \\
(n=21)\end{array}$} & $\begin{array}{l}\text { Toronto } \\
(3.05 M d o \\
(n=1)\end{array}$ \\
\hline & $\begin{array}{r}28 \\
15 \\
0 \\
6 \\
7\end{array}$ & $(29 \cdot 5)$ & $\begin{array}{l}0 \\
0 \\
0 \\
0 \\
0\end{array}$ & $\begin{array}{l}4 \\
2 \\
0 \\
0 \\
2\end{array}$ & $(20 \cdot 0)$ & $\begin{array}{ll}8 & (22 \cdot 9) \\
7 & \\
0 & \\
1 & \\
0 & \end{array}$ & $\begin{array}{l}7 \\
0 \\
1 \\
1 \\
5\end{array}$ & $(63 \cdot 6)$ & $\begin{array}{r}17 \\
0 \\
0 \\
16 \\
1\end{array}$ & $(81 \cdot 0)$ & $\begin{array}{ll}1 & (100) \\
1 & \\
0 & \\
0 & \\
0 & \end{array}$ \\
\hline $\begin{array}{l}\text { Serogroup WII/III: } \\
\text { Bopst } \\
\text { Bpyvut } \\
\text { Bropt } \\
\text { Bropyst } \\
\text { Brpyt } \\
\text { Brpyust } \\
\text { Bys } \\
\text { Av/Bx } \\
\text { Other }\end{array}$ & $\begin{array}{r}67 \\
0 \\
12 \\
18 \\
0 \\
0 \\
0 \\
0 \\
11 \\
26\end{array}$ & $(70 \cdot 5)$ & $\begin{array}{l}2 \\
0 \\
0 \\
0 \\
0 \\
0 \\
2 \\
0 \\
0 \\
0\end{array}$ & $\begin{array}{r}16 \\
0 \\
8 \\
5 \\
0 \\
0 \\
0 \\
0 \\
0 \\
3\end{array}$ & $(80 \cdot 0)$ & $\begin{aligned} 27 & (77 \cdot 1) \\
0 & \\
0 & \\
8 & \\
0 & \\
0 & \\
10 & \\
0 & \\
0 & \\
9 & \end{aligned}$ & $\begin{array}{l}4 \\
0 \\
0 \\
1 \\
2 \\
0 \\
0 \\
1 \\
0 \\
0\end{array}$ & $(36 \cdot 4)$ & $\begin{array}{l}4 \\
1 \\
1 \\
1 \\
0 \\
1 \\
0 \\
0 \\
0 \\
0\end{array}$ & (19.0) & $\begin{array}{l}0 \\
0 \\
0 \\
0 \\
0 \\
0 \\
0 \\
0 \\
0 \\
0\end{array}$ \\
\hline
\end{tabular}

carrying the 3.2 megadalton (African type), and only one harbouring the 3.05 megadalton (Toronto type) penicillin resistance plasmids. Correlation between plasmid content and serogroups and serovars was also observed (table 4). Of the 21 PPNG strains carrying the 4.5 megadalton resistance plasmid, $17(81 \%)$ belonged to the WI and only four (19\%) to the WII/III serogroup. Most (16/17, of the 4.5 megadalton WI strains were of serovar Arst, whereas each of the four 4.5 megadalton WII/III strains had a different serovar. The 11 PPNG strains harbouring the 3.2 megadalton resistance plasmid were distributed as follows: seven $(63.6 \%)$ were in the WI serogroup and Av was the predominant serovar; the remaining four $(36.4 \%)$ belonged to serogroup WII/III and were of Bropyst (2), Bropt (1), and Bys (1) serovars. The one strain harbouring the 3.05 megadalton resistance plasmid belonged to serogroup WI and was of serovar Arost.

\section{Discussion}

Classifying gonococcal strains, based on their nutritional requirements, serogroups, serovars, and plasmid content, is a powerful tool for analysing the epidemiology of infections with non-PPNG and PPNG strains. ${ }^{3819}$ These traits not only play an important part in studying the epidemiology of outbreaks of infections with PPNG strains and strains resistant to other antibiotics such as tetracycline, ${ }^{820-22}$ but also constitute excellent epidemiological markers for monitoring changes in the phenotypes of gonococci. ${ }^{2022} 23$

Our results agree with those of previous observations regarding the serological classification of gonococci in Canada, Thailand, Singapore, Korea, areas of
Europe, the United States of America, Australia, and Africa, where most non-PPNG strains belong to the WII/III serogroup. ${ }^{419202224-29}$ Indeed, $73.7 \%$ of the non-PPNG Greek isolates were in serogroup WII/III, whereas only $26 \cdot 3 \%$ belonged to serogroup WI. In terms of serovars, the most common in serogroup WI was Arost (38.5\%), which was rarely associated with infections by PPNG strains-results similar to those observed by other workers. ${ }^{1925}$ On the other hand, the most common serovar among our WII/III gonococcal strains was Bropt $(27.5 \%)$. The incidence $(25 \%)$ of serovar Bropt in our PPNG strains was similar to that observed in South East Asia (Bangkok 23\%, Korea $21 \%)^{25}$

Our findings regarding their nutritional requirements show that the Zero and $\mathrm{Pro}^{-}$strains predominated, followed by Arg strains, which confirms observations made by other workers in areas such as Canada, the USA, and Europe. ${ }^{13031}$ Most of the prototrophic, $\mathrm{Pro}^{-}, \mathrm{Arg}^{-}$, and $\mathrm{PCU}^{-}$isolates belonged to serogroup WII/III, as expected. Most of the AHU' strains, however, were in serogroup WI, which confirmed Danielson's and Sandström's finding of a strong correlation between $\mathrm{AHU}^{-}$strains and serogroup WI. ${ }^{3132}$ The observation of other workers that there is a greater diversity of serovars in serogroup WII/III than in serogroup WI agrees with our results.

Differences in susceptibility to antimicrobial agents between serogroups have been also noted by other workers. ${ }^{232533}$ Our WI serogroup strains were more sensitive to penicillin, thiamphenicol, tetracycline, and cefotaxime, whereas our strains in the WI and WII/III serogroups were equally sensitive to spectinomycin. The strains of the Arost serovar, which predominated in serogroup WI, showed an overall sensitivity, 
whereas serovar Bropt strains were appreciably more resistant to antimicrobial agents (data not shown); similar findings have also been reported previously. ${ }^{19}$

Correlation between serogroup and plasmid content showed that the WII/III serogroup predominated in non-PPNG strains, regardless of their plasmid content. In the WII/III strains lacking the 2.6 megadalton cryptic plasmid (those that were plasmid free or harbouring the 24.5 megadalton conjugative plasmid only) the predominant serovar was Brpyust, which was rare in the other plasmid content groups of the WII/III strains.

Most $(25 / 33,75.8 \%)$ PPNG (in contrast to nonPPNG) strains were shown to belong to serogroup WI. When serovars were analysed, five out of the seven strains belonging to the WI serogroup and harbouring the African type resistance plasmid (3.2 megadalton) were of serovar Av and auxotype Zero, which has also been found in Canada, Sweden, and The Netherlands. ${ }^{6} 1920$ Though 3.2 megadalton Av serovar PPNG strains have been isolated in Sweden, they had been imported there from Africa and the same serovar was also probably imported to Greece. On the other hand, the combinations of serovar and auxotype in the four 3.2 megadalton WII/III strains suggested that PPNG strains had also been imported from Asia, which confirms the observations made by other workers. ${ }^{25}$

The combination of serovar and auxotype in the 4.5 megadalton WI strains, such as Arst/Pro and Arst/ Zero, shows that those strains were of Asian origin, ${ }^{25}$ though the Arst/Pro ${ }^{-}$combination has also been found in Africa.

It is worth noting that the combinations Bopst/Zero and Bpyvut/Zero were isolated for the first time in Greece, whereas the Bropt $/ \mathrm{Pro}^{-}$and Brpyt $/ \mathrm{Pro}^{-}$combinations have also been found in Asia and Europe (data not shown).

In conclusion, our results confirm correlation between serotype, auxotype, susceptibility to antimicrobials, and plasmid content noted by other workers. ${ }^{2-4618-2025}$ They also suggest that most of our PPNG strains were imported from Asia, although some were imported from Africa and Europe. As Greece is a naval and tourist country, these findings are not surprising. This study has also shown that certain WII/III serovars correlated highly with resistance to antibiotics, that the presence or absence of transfer and cryptic plasmids correlated with serovar, and that the distribution of PPNG strains can be characterised in part by analysing serovar, auxotype, and plasmid content.

We thank Dr Solgun Bygdeman of the sexually transmitted diseases research group of the Huddinge Hospital, Sweden, for providing the serological reagents and control strains, and Dr J Y Riou of the neisserial laboratory of the Pasteur Institute, Paris, for providing the control strains for auxotyping and analysing susceptibility to antimicrobials.
References

1 Catlin BW. Nutritional profiles of Neisseria gonorrhoeae, Neisseria meningitidis and Neisseria lactamica in chemically defined media and the use of growth requirements for gonococcal typing. J Infect Dis 1973;128:178-94.

2 Bygdeman S, Danielson D, Sandström E. Gonococcal W serogroups in Scandinavia. A study with polyclonal and monoclonal antibodies. Acta Pathol Microbiol Immunol Scand [B] 1983;91:293-305.

3 Danielson D, Bygdeman S, Kallings I. Epidemiology of gonorrhoea: serogroup, antibiotic susceptibility and auxotype patterns of consecutive gonococcal isolates from ten different areas in Sweden. Scand J Infect Dis 1983;15:33-42.

4 Handsfield HH, Sandström EG, Knapp JS, Sayers DE, Whittington WL, Holmes KK. Epidemiology of penicillinase producing Neisseria gonorrhoeae infections. Analysis by auxotyping and serogrouping. N Engl J Med 1982;306:950-4.

5 Knapp JS, Tam MR, Nowinski RC, Holmes KK, Sandström EG. Serological classification of Neisseria gonorrhoeae with use of monoclonal antibodies to gonococcal outer membrane protein I. J Infect Dis 1984;50:44-8.

6 Ramstedt KM, Hallhagen GJ, Bygdeman SM, et al. Serologic classification and contact-tracing in the control of microepidemics of $\beta$-lactamase producing Neisseria gonorrhoeae. Sex Transm Dis 1985;12:209-14.

7 Dillon JR, Pauzé M, Gould R, Sutherland R, Romanowski B. Penicillinase producing Neisseria gonorrhoeae with $\mathrm{Pro}^{-} \mathrm{Orn}^{-}$ WI Asia ${ }^{+}$phenotype. Lancet 1986;:103-4.

8 Plummer FA, D'Costa LJ, Nsanze $\mathrm{H}$, et al. Development of endemic penicillinase producing Neisseria gonorrhoeae in Kenya. In: Schoolnik GK, Brooks G, Falkow JS, et al, eds. The pathogenic neisseriae. Washington DC, American Society of Microbiology, 1985:101-6.

9 Easmon CSF. Gonococcal resistance to antibiotics. J Antimicrob Chemother 1985;16:409-12.

10 Riou JY, Lind I, Guibourdenche M. Antibiotic susceptibility of 83 penicillinase-producing Neisseria gonorrhoeae strains isolated in France (May 1979-April 1983). J Antimicrob Chemother 1985;16suppl A:209-12.

11 Riou JY, Guibourdenche M, Courvalin P. Antibiotic susceptibility testing of Neisseria gonorrhoeae by disk-agar diffusion. Ann Inst Pasteur Microbiol 1985;132B:23-39.

12 Catlin BW. Characteristics and auxotyping of Neisseria gonorrhoeae. In: Bergan T, Norris JR, eds. Methods in microbiology. Vol 10: London: Academic Press, 1978:345-80.

13 Hendry AT, Steward IO. Auxanographic grouping and typing of Neisseria gonorrhoeae. Can J Microbiol 1979;25:512-21.

14 Portnoy DA, Moseley SL, Falkow S. Characterization of plasmids and plasmid-associated determinants of Yersinia enterocolitica pathogenesis. Infect Immun 1981;31:775-82.

15 Maniatis T, Fritsch EF, Sambrock J. Molecular cloning: $a$ laboratory manual. Cold Spring Harbor, New York: Cold Spring Harbor Laboratory, 1982:458-9.

16 Bygdeman SM, Gillenius EC, Sandström EG. Comparison of two different sets of monoclonal antibodies for the serological classification of Neisseria gonorrhoeae. In: Schoolnik GK, Brooks G, Falkow JS, et al, eds. The pathogenic neisseriae. Washington DC: American Society of Microbiology, 1985: 101-6.

17 Sandström EG, Lindell P, Härfast B, Blomberg F, Ryden AC, Bygdeman SM. Evaluation of a new set of Neisseria gonorrhoeae serogroup $\mathrm{W}$-specific monoclonal antibodies for serovar determination. In: Schoolnik GK, Brooks G, Falkow JS, et al, eds. The pathogenic neisseriae. Washington DC: American Society of Microbiology, 1985:26-30.

18 Dillon JR, Carballo M, King SD, Brathwaite AR. Auxotypes, plasmid contents, and serovars of gonococcal strains (PPNG and non-PPNG) from Jamaica. Genitourin Med 1987;63:233-8.

19 Dillon JR, Bygdeman SM, Sandström EG. Serological ecology of Neisseria gonorrhoeae (PPNG and non-PPNG) strains: 
Canadian perspective. Genitourin Med 1987;63:160-8.

20 Knapp JS, Sandström EG, Holmes KK. Overview of epidemiological and clinical applications of auxotype/serovar classification of Neisseria gonorrhoeae. In: Schoolnik GK, Brooks G, Falkow JS, et al, eds. The pathogenic neisseriae. Washington DC: American Society of Microbiology, 1985:6-12.

21 Young K-H, Dillon JR, Pauzé M, Wallace E. Outbreak of PPNG caused by a novel 3.05 Mdal penicillinase-producing plasmid (Toronto-type) related to the Asian-type plasmid. J Infect Dis 1986;153:1162-5.

22 Whittington WL, Vernon A, Biddle JW, et al. Serological classification of Neisseria gonorrhoeae: uses at the community level. In: Schoolnik GK, Brooks G, Falkow JS, et al, eds. The pathogenic neisseriae. Washington DC: American Society of Microbiology, 1985:20-5.

23 Bygdeman S. Serological classification of Neisseria gonorrhoeae. Relation to antibiotic susceptibility and auxotypes. Epidemiological applications. Stockholm: Karolinska Institute, 1981. PhD thesis.

24 Brunham RC, Plummer F, Slaney L, Rand F, DeWitt W. Correlation of auxotype and protein I type with expression of disease due to Neisseria gonorrhoeae. J Infect Dis 1985;152. 339-43.

25 Bygdeman SM. Polyclonal and monoclonal antibodies applied to the epidemiology of gonococcal infection. In: Young $\mathbf{H}$, McMillan A, eds. Immunological diagnosis of sexually transmitted diseases. New York: Marcel Decker, 1987:117-65.
26 Odugbemi TO, Brown ST, Biddle J, et al. Plasmid profile, serogrouping of Neisseria gonorrhoeae isolates from Africa. British Journal of Venereal Diseases 1983;59:41-3.

27 Odugbemi TO, Whittington WL, DeWitt W, et al. Epidemiological characterisation of Neisseria gonorrhoeae isolates from the Far East. British Journal of Venereal Diseases 1983;59: 285-8.

28 Yvert F, Frost E, Guibourdenche M, Riou JY, Ivanoff B. Auxotypes and serogroups of penicillinase producing and nonproducing strains of Neisseria gonorrhoeae isolated in Franceville, Gabon. Genitourin Med 1985;61:99-102.

29 Ansink-Schipper MC. Auxanographic typing of Neisseria gonorrhoeae isolated in The Netherlands. Amsterdam: University of Amsterdam, 1985. PhD thesis.

30 Dillon JR, Pauzé M. Resistance to antimicrobial agents. What next for Neisseria gonorrhoeae? Sex Transm Dis 1984;11 suppl:353-9.

31 Sandström EG. Studies on the serology of Neisseria gonorrhoeae. Stockholm: Karolinska Institute, 1979. PhD thesis.

32 Sandström EG, Knapp JS, Reller B, Thompson S, Hock EW, Holmes KK. Serogrouping of Neisseria gonorrhoeae: correlation of serogroup with disseminated gonococcal infection. Sex Transm Dis 1984;11:77-80.

33 Bygdeman S, Mårdh P-A, Sandström EG. Susceptibility of Neisseria gonorrhoeae to rifampicin and thiamphenicol. Correlation to protein I antigenic determinants. Sex Transm Dis 1984;11:366-70. 